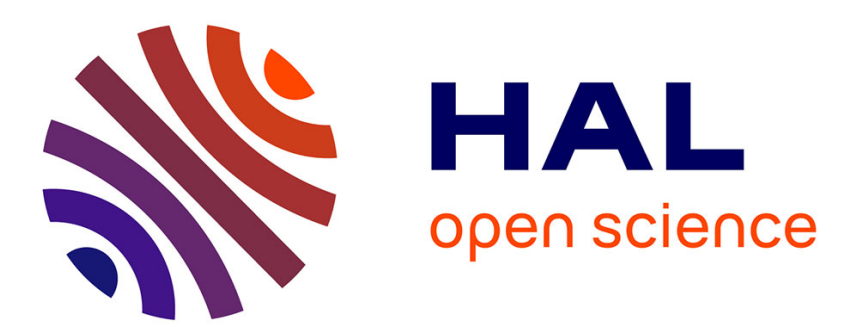

\title{
Technological contribution of MNEs to the growth of energy-greentech sector in the early post-Kyoto period
}

Patricia Laurens, Christian Le Bas, Antoine Schoen, Stéphane Lhuillery

\section{To cite this version:}

Patricia Laurens, Christian Le Bas, Antoine Schoen, Stéphane Lhuillery. Technological contribution of MNEs to the growth of energy-greentech sector in the early post-Kyoto period. RIODD 2016, Jul 2016, Saint-Étienne, France. hal-01349964

\section{HAL Id: hal-01349964 \\ https://hal.science/hal-01349964}

Submitted on 29 Jul 2016

HAL is a multi-disciplinary open access archive for the deposit and dissemination of scientific research documents, whether they are published or not. The documents may come from teaching and research institutions in France or abroad, or from public or private research centers.
L'archive ouverte pluridisciplinaire HAL, est destinée au dépôt et à la diffusion de documents scientifiques de niveau recherche, publiés ou non, émanant des établissements d'enseignement et de recherche français ou étrangers, des laboratoires publics ou privés. 


\title{
Technological contribution of MNEs to the growth of energy-greentech sector in the early post-Kyoto period
}

\section{Patricia LAURENS}

Université Paris-Est, CNRS-LISIS-IFRIS,

Adresse : 2, bd Blaise Pascal, 93160 Noisy Le Grand (France)

E-mail : p.laurens@esiee.fr

\section{Christian LE BAS ${ }^{1}$}

ESDES School of Management, Catholic University of Lyon, Adresse : 16, rue de l'Abbaye d'Ainay, 69002 Lyon (France)

E-mail : clebas@univ-catholyon.fr

\section{Antoine SCHOEN}

Université Paris-Est, ESIEE-LISIS-IFRIS,

Adresse : 2, bd Blaise Pascal, 93160 Noisy Le Grand (France)

E-mail : antoine.schoen@esiee.fr

\section{Stéphane LHUILLERY}

Université de Lorraine, BETA (UMR-CNRS 7522),

Adresse : 13 place Carnot, $\mathrm{CO} \mathrm{n}^{\circ} 70026,54035$ Nancy (France)

E-mail : stephane.lhuillery@icn-groupe.fr

\begin{abstract}
We consider the commitment of large firms with high R\&D investments to the development of technologies of climate change mitigation related to the production or storage of energy. We analyse such Climate Change Mitigation Technologies focused on energy production and storage (energy CCMT) across the globe with the aim of assessing whether the Kyoto Protocol fosters the diffusion of inventive activity in energy greentech. Using patents as the key dataset, we give an empirical description of the corporate patenting activity and assess its contribution to the overall energy CCMT inventions across countries and sectors of energy greentech before and after the signing of the Kyoto Protocol (1997). Our observations
\end{abstract}

\footnotetext{
${ }^{1}$ Corresponding author: Christian Le Bas, ESDES School of Management, Catholic University of Lyon, 10, place des Archives -, 69002 Lyon (France), clebas@univ-catholyon.fr
} 
indicate that climate change issues and greentech development have not been prioritized to the same extent by firms of western countries as opposed to, for example, Japanese firms in the beginning of the 2000s. However, we witness a growing commitment in most of the western countries. US large firms were more prone to gain skills in renewable energy technologies than most of their European counterparts, which continue to heavily invest in traditional energies such as Nuclear energy and Combustion.

Key-words: Innovation, MNE, Energy cleantech, Patent, Kyoto Protocol

Journal of Economic Literature classification numbers: O33, Q55

\section{Technological contribution of MNEs to the growth of energy-greentech sector in the early post-Kyoto period}

\section{Introduction}

The world conference held in Kyoto (Dec. 1997) is acknowledged as opening a new area in the battle for climate change. It will have durably changed the firm vision about the environmental concerns. How has the greentech technological activity progressed in large firms in the postKyoto period? How much is greentech technology being patented by MNEs? In which type of energy clean technologies are the large firms most active after Kyoto (energy sources vs. energy storage, «traditional » nuclear fission vs. renewable energy production)? The paper at hand tries to answer these questions.

The paper contributes to the literature dealing with the firms' commitment to the bulk of inventions in the field of energy green technologies (energy greentech or greentech hereafter) by quantifying the innovative production in that field before and after the signing of the Kyoto Protocol (1997). We focus on large innovative firms and observe if and how they have reacted 
to the Kyoto Protocol by tracking the change of their patenting behaviour from a pre-Kyoto period (1994-1996) to an early post-Kyoto period (2003-2005). When a large firm starts to invest or to intensify its investments in the knowledge related to energy greentech, it diversifies its technological knowledge base. Such a process differs across large firms due to the history of the firm, its own initial and past specialization, the specific national institutional setting in which companies are embedded (see Breschi et al. 2003). Large firm invention activity lies at the core of our study but an analysis based on the country of origin of the firm is preferred for delineating the main quantitative trends. Two evidences justify this approach: 1) the home domestic base still stays important for large often multinational firms (Laurens et al., 2015), 2) for this kind of firm, national energy policy creates strong incentives in favour of green energy technologies (see for instance Popp et al., 2011).

This research is part of the general theoretical framework of the theory of diffusion of technology. Clean technologies related to energy can be considered to be general purpose technologies shaping a wide array of environmental innovations related to energy - much like information and communication technologies do, to an even wider extent. Such technologies diffuse through a wide variety of industrial sectors and technologies all over the world. According to this perspective, we do not study the diffusion of a given technological novelty through a group of firms belonging to the same industry. Thus we cannot use the well-known models (such as epidemics models, S-shaped curves, saturation or percolation structures) for analysing the scale, rhythm and determinants of innovation diffusion (for a list of these models see for instance Swann, 2009). Nevertheless, we can support our research on several theoretical results that help frame the diffusion of clean technologies related to energy. For instance 
according to the directed technological change approach proposed by Acemoglu (2002), energy prices and market size plays a crucial role for reorienting R\&D towards greener technology projects. Nevertheless the two effects act in opposite direction: the price effect encourages innovation directed at scarce factors, the market effect lead to innovation favouring abundant factors. The degree of substitution between these two determinants plays a role: when they are substitutable le market size effect is larger. The analysis is more complex in the sense Acemoglu considers as well the degree of R\&D state-dependence or in other words past-dependence (see Acemoglu et al., 2012). Temporary taxes and R\&D subsidies redirect innovation towards clean energy inputs (Acemoglu et al., 2012) and promote the diffusion of energy green technologies. Specific taxes (that make the "dirty product" more costly) and R\&D subsidies (for supporting "clean" projects) provide incentives to create new "clean products" and foster the introduction of cleaner technologies and environmental improvements (Rennings, 2000).

Verdolini and Galeotti (2011) have thus confirmed empirically the role of energy prices effects coupled to technological opportunities effects. Popp et al. (2011) when analysing renewable energy have confirmed that the role of policy-induced substitution is larger than technology push dynamics. The energy technology process has specific features that impede the identification of a simple trend. On the one hand the supplier/user relationship is more complex in that the suppliers of energy equipment are not always linked to the final user, on the other, this activity has a strong systemic dimension (Oltra et al, 2009). Moreover, evolutionary economics of environmental innovation (Horbach et al., 2011; Mowery, Nelson, Martin, 2010; Ghisetti and Quatraro, 2014) put forth the role and variety of institution types and the notion of technological trajectory (Antonelli, 2011). 
The paper is organized as follows. The first section delineates the context of energy greentech at the world and nation levels. The role of national energy policies is pointed as the impact of the different actors (industrial firms in particular). Section 2 presents the research questions. Section 3 offers information on the data set, the characteristics of the sample of firms and the definition of the indicators. Section 4 provides results and shows new trends related to the large firms' contribution to cleaner environment. In the last section we discuss our findings, highlighting the role of major firms from Japan, USA and Europe.

\section{1 : The energy greentech context: a brief overview from national policy to corporate technology activity}

Climate change issues have become a global concern putting pressure on decision makers within governments and corporations. Since 1992 obligations were taken to address climate change issues (Borghesi \& al., 2002). The Kyoto Protocol (1997), which established emission reduction targets, was rejected by the US in 2001 arguing of absence of obligations for all GHG emitters and possible negative effects on the US economy ${ }^{2}$. Many new regional and national policies followed the signing of the Kyoto Protocol where developed countries agreed to limit emissions of greenhouse gases.

\section{1 : First steps in greentech}

The extent and scope of State support differs across countries. Several European countries have emerged as early movers in promoting the supply and demand of clean energy and EU policies have reinforced member States' programs (promoting high R\&D levels, the pre- emption of the

\footnotetext{
${ }^{2}$ In 2011, Canada also withdrew from the Accord.
} 
EU internal market with an early positioning in countries such as Germany, the UK and Italy, and public incentives and standards promoting EU technology deployment). Japan was also an early mover in cleantech. Without national energy resources, it got engaged in environmental innovation policy after the oil shocks (the Sunshine Programme was designed to introduce solar power in the 1970s). These developments were partly responsible for establishing major Japanese solar photovoltaic (PV) manufacturers and a thriving solar industry (Foster, 2010) ${ }^{3}$. Conversely the United States has suffered from the lack of a coherent national energy policy and of an effective legislation creating incentives for renewables development although, at the state level, policies fostering clean energy industries have been implemented.

\section{2 : Evidence for technological development in greentech}

The correlation between political decisions resulting from the signing of the Kyoto Protocol and the take-off of clean-energy technologies was documented (Jaffe, 2003; Johnstone, 2010; Veugelers, 2011). In order to measure the stimulation of greentech, many scholars used surveys ${ }^{4}$ or patent data (Popp, 2005). The latter is considered to correctly reflect the level of R\&D investments (Griliches, 1990) and are adapted to investigate the consequences of the public policy framework put in place to support the development of cleantech. Patent data offers accessibility over long periods of time, provide information regarding applicants' name and location while covering worldwide inventive activity.

\footnotetext{
${ }^{3}$ Japan was the first country to reach $1 \mathrm{GW}$ of installed solar capacity in 2004 thanks to the first subsidy programme started in 1994 for residential solar panels.

${ }^{4}$ Since 2006 the Community Innovation Survey reports information concerning the adoption of energy-saving technologies in firms. Many papers now make use of the data stemming from this survey.
} 
Several studies have investigated the rise of greentech patenting since the end of the 1990s and put forward the leading role of developed countries, in particular Japan (plus United States, and Germany) but also the significant contribution of new comers like Korea, China or Russia at USPTO (Dechezleprêtre, 2009 and 2011; Mark and Siddharth, 2012). Using patent data, Dechezleprêtre (2009) (like Lanjouw and Mody, 1996) finds that US, Japan, and Germany account for two-thirds of the climate-friendly inventions. They emphasize the role of policy in the greentech innovation increase that occurred after the Kyoto Protocol in all countries except in the US and Australia that had not ratified the Kyoto Protocol ${ }^{5}$. Using a panel of patent data from OECD countries for exploring the development of renewable energy technologies, Johnstone et al. (2010) show a rapid growth in wind and solar energy patent activity, particularly since the mid-1990s and find that public funded R\&D programs increased patenting activity for the sponsored technologies. However their effects on innovation in renewable energy differ across technologies.

\section{3 : Large firms and greentech}

Scarce information is available on the contribution of the different actors from the business sector to green technology innovation. The quest for social and environmental sustainability has transformed the landscape of global competition (Nidumolu, 2009). Large firms accused of being major contributors to various environmental problems as a result of their worldwide operations (Christmann, 2004; Christmann and Taylor, 2001; Strike, Gao and Bansal, 2006) give a high priority to the reduction and eventual elimination of GHG emissions. Climate change mitigation efforts are positive signals towards the consumers, can 
offer potential market opportunities in new products and technologies and save cost from lower energy use (McWilliams and Siegel, 2000; Cohen and Levinthal, 1990; Grant, 1996; Begg, van der Woerd and Levy, 2005; Margolick and Russell, 2001; Reinhardt, 2000).

Despite the fact that they face common threats and opportunities, there was a striking variation in the responses of companies across sectors and countries (Falkner 2010). As a whole, European industry has displayed a readiness to invest in technologies that might reduce greenhouse gas emissions. In the 1990s, US-based companies were very active in challenging the climate change mitigation. Large firms on both sides of the Atlantic appeared to converge in the 2000s toward a shared acknowledgement of the role of GHGs in climate change and the need for some action. The impact of MNEs' home country policies on corporate strategies is likely to diminish over time as industries become more international in scope (Levy and Kaplan, 2007).

Since the early 2000s many illustrations of the commitment of MNEs in greentech can be found in the academic literature and in the media. Pernick and Wilder (2007) present examples that show that the "clean tech revolution" is already under way. Very large corporations such as Intel, General Electric, Toyota, Sharp, Total, Chevron, Daimler reported large investments in clean technology, through R\&D programmes, partnerships or start-ups acquisitions. Traditional energy companies like Total became involved in solar power (acquiring SunPower, Silicon Valley's dominant solar-panel maker). Among the dominant players in corporate cleantech are: $\mathrm{ABB}$ (world leader in power grids), Siemens and Schneider Electric that specializes in 
energy management ${ }^{6}$. The adaptive responses of firms to the climate change challenge also depend on the industry itself. Companies from petroleum-gas, automotive, energy, home appliances and metal/mining industries, which are closely related to climate change issues due to their energy needs, their processes and their outputs - are more sensitive to the climate change (Deegan and Gordon, 1996; Lang and Lundholm, 1993). However the ability of sectors to develop green competitiveness based on their existing comparative advantages, skills and production patterns is uneven across countries (Frankhauser, 2013). Multinational companies are more responsive to climate change when compared with national enterprises (Kaya, 2008). However, it has also to be kept in mind that R\&D investments in the field of energy/electricity have dramatically declined in the developed countries over the last decades to the exception of state-owned enterprises (Sterlacchini, 2012).

\section{2 : Research questions}

To date, there is no global picture targeting the diffusion of energy greentech in large firms. Our aim is to qualify, from the pre-Kyoto to the post-Kyoto periods, the trends in the contribution of large firms to the global greentech innovative production across countries. We focus on the energy sector and consider technologies related to energy production and energy storage that mitigate climate change $e^{7}$ We use the terms cleantech or greentech when referring to these technologies.

In the context of R\&D public policy and large firm strategy in the area of energy greentech, we address four questions:

\footnotetext{
${ }^{6}$ All these large firms are included in the set of large firms with the highest R\&D investments used in this work.

${ }^{7}$ Technologies related to smart grids and the capture of $\mathrm{CO}_{2}$ are not included.
} 
1. The first investigation aims at measuring the contribution of large firms involved in energy green technologies arcoss countries and investigate their evolution in order to assess the likely diversification in favour of green technologies. We explore how many firms are involved with energy greentech in the pre-Kyoto period and how many have entered a process of diversification towards energy greentech after the adoption of the Kyoto Protocol.

2. The second aspect aims to determine if (and to which extent) large innovative firms increased their inventive production in energy greentech after the Kyoto protocol. In order to appreciate if large firms get more and more involved in green technologies, we compare their relative volume of patents in energy greentech in the pre- and post-Kyoto periods of time.

3. In order to compare the efforts of large firms, we rely on their specialization in energy greentech. We assess the scale and evolution of the large firm relative specialization in green technologies through a green specialization index. It reveals in which countries firms have done more efforts to reinforce their specialization in energy greentech.

4. Finally, we identify the sectors of energy greentech in which the large firms are the most active. For this, we detail the green specialization of firms at the level of green subsectors and follow their evolution over time.

\section{3 : Data and sampling}

\section{1 : Database building}

This research uses patent information extracted from the Patstat database (2011), which includes all patents applied for through the world in one of the 180 national, regional and international 
patent offices. We retrieve first filings (priority patent applications ${ }^{8}$, i.e. the very first patent application for a novelty) without any patent office restriction from 1994 to 2005 and select patents filed by firms from 1994 to 1996 as the set of patents of a pre-Kyoto period. In a similar way, we select patents filed by from 2003 to 2005 as the set of patents of a post-Kyoto period ${ }^{9}$. We select a corpus of firm patents by gathering together those patents filed by any legal entity which belongs to the set of 946 large firms which have filed at least 5 priority patents in any technology during both the pre-Kyoto (1994-1996) and post- Kyoto (2003-2005) periods. These firms were selected from an initial list of more than 2000 large industrial companies with the highest annual R\&D investments provided by the Industrial R\&D Investment Scoreboard 2008 (1000 European firms and 1000 non European firms $)^{10}$. For each firm, the patent portfolio was built using the Orbis database ${ }^{11}$ by including applications originating from the firm and from all identified subsidiaries in which the firm had more than $50.01 \%$ of shares (see Laurens et al., 2015 for methodological details on delineation of the consolidated corporate patent portfolios).

\footnotetext{
${ }^{8}$ Considering priority patents applied without any patent office restriction we encompass all greentech activity (de Rassenfosse et al., 2013) while most of published studies select valuable patents (i.e. PCT patents or patents applied or granted at USPTO).

${ }^{9}$ The number of energy greentech patents applied for by large firms each year is very low in many countries before the signing of the Kyoto Protocol in 1997 (around 150 in Germany but only around 40 in France, 15 in the UK ...). Therefore we calculate indicators on a 3 year period of time to obtain more robust indicators in the pre-Kyoto period that we compare with those calculated on a 3 year period of time in the post-Kyoto period.

${ }^{10}$ The list of the firms included in the Industrial R\&D Investments Scoreboard (edition 2008) is given in http://iri.jrc.ec.europa.eu/scoreboard.html.

${ }^{11}$ Edited by Bureau van Dijk Electronic Publishing.
} 
Each firm is assigned to a country according to the location of its headquarters and its patents are assigned to the country of the headquarters of the firm to whom the applicant belongs ${ }^{12}$.

The 946 firms are roughly equally distributed between the US (34\%), Asia (27.2\%) and Europe (35.7\%) (Table 2). In North America, firms in Technology (33\%), Industrial goods and services (18\%) and Health cares (13\%) dominate. In Europe, Industrial goods and services (27\%), Consumer goods (17\%) and Industrials (13\%) are the most represented industries. In Asia, the principal industrial sectors are Industrial goods and services (24\%), Consumer goods (21\%) and Basic Materials (19\%).

Among the overall firm priority patent portfolios, we retrieve energy cleantech patents from the Y02E subclass of the CPC classification ${ }^{13}$. It covers technologies dealing with the reduction of GHG emission, related to energy generation, transmission or distribution (Veefkind, 2012) and includes Technologies with contribution to GHG emissions mitigation (energy storage (batteries), fuel cells, hydrogen technology), Renewable energy sources (photovoltaic, wind, thermal solar, hydro, oceanic and geothermal energies), Technologies for the production of fuel of non-fossil origin (biofuel from energy using wastes), Combustion technologies with mitigation potential (Combined Heat and Power ...); Nuclear Energy and Technologies for efficient electrical power generation, transmission or distribution.

\footnotetext{
${ }^{12}$ For example if the applicant of a patent is located in country B and is a subsidiary of a large firm with headquarters in country A, the patent is attributed to the corporate patent portfolio of country A.

${ }^{13}$ YO2 class was set up by EPO in 2010 to tag technologies which "control, reduce or prevent GHG emissions of anthropogenic origin" as set forth by the Kyoto Protocol.
} 
3.2 : Indicators of energy greentech specialization

Let us use $i=1,2,3 \ldots n$ to index firms; $j=1,2,3 \ldots m$ to index countries and $g=1$ to 7 to index sub sectors in energy greentech.

We formally consider the firm patenting at time $t$ as:

Pij $(t)=$ firm $i$ from country $j$ new patents at time $t$ (green technology patents included)

Pgij $(t)=$ firm $i$ from country $j$ new patents in energy green technologies sub sector $g$ at time $t$

We measure the volume of firm i patenting in energy greentech inventions (whatever the type of sub sector) as

$$
p^{g}{ }_{i j}(t)=\Sigma_{g} P_{i j}^{g}(t)
$$

We measure the firm i contribution to energy green tech as:

$$
e^{g_{i j}}(t)=p^{g_{i j}}(t) / P_{i j}(t)=\Sigma_{g} P_{i j}^{g}(t) / P_{i j}(t)
$$

The index of specialization in energy green technologies is defined for firm i from country $j$ and the time period $t$ as:

$$
\mathrm{G}_{\mathrm{ij}}(\mathrm{t})=\mathrm{e}^{\mathrm{g}}{ }_{\mathrm{ij}}(\mathrm{t}) /\left(\Sigma_{\mathrm{i}} \mathrm{P}^{\mathrm{g}}{ }_{\mathrm{ij}}(\mathrm{t}) / \sum \Sigma_{\mathrm{ij}} \mathrm{P}_{\mathrm{ij}}(\mathrm{t})\right)
$$

where $\sum \mathrm{i}$ Pgij indicates all energy green patents in our data set (for time $\mathrm{t}$ ) and $\sum \sum \mathrm{ij} \mathrm{Pij}(\mathrm{t})$ the overall set of patents (whatever the technological field and for the overall number of firms and for time $\mathrm{t})$. 
Firm $i$ has a relative specialisation in energy greentech when Gij $(t)>1^{14}$. The higher Gij $(t)$, the more specialised firm $i$ is.

The index of specialization in a subsector $g$ of energy green technologies, SGgij relates to the firm $\mathrm{i}$ (from country $\mathrm{j}$ ) contribution to a subsector g of energy greentech inventions among energy greentech inventions. It is expressed as:

$$
\mathrm{SG}^{\mathrm{g}} \mathrm{ij}_{\mathrm{j}}(\mathrm{t})=\left(\mathrm{P}_{\mathrm{ij}}^{\mathrm{g}}(\mathrm{t}) / \Sigma_{\mathrm{g}} \mathrm{P}_{\mathrm{ij}}^{\mathrm{g}}(\mathrm{t})\right) /\left(\sum_{\mathrm{i}} \mathrm{P}_{\mathrm{ij}}^{\mathrm{g}}(\mathrm{t}) / \Sigma \Sigma_{\mathrm{ij}} \mathrm{P}_{\mathrm{ij}}^{\mathrm{g}}(\mathrm{t})\right)
$$

Firm $\mathrm{i}$ has a relative specialisation in the subsector $\mathrm{g}$ when SGgij $(\mathrm{t})>1$. The higher SGgij $(\mathrm{t})$, the more specialised firm $\mathrm{i}$ is.

\section{3 : Overall characterisation of the database}

Between 1994 and 2005, the 946 firms applied for 3590310 priority patents, among which 72 565 are greentech patents. Technologies included relate to energy storage, hydrogen and fuel cells dominate in firm greentech patents (Table 1). Then come technologies for renewable energies, combustion and nuclear energy.

Table 1: Energy greentech patents of firms across greentech sectors (1994-2005)

\begin{tabular}{|l|l|}
\hline Energy greentech subsectors & $\begin{array}{l}\text { Distribution } \\
(\mathbf{\%})\end{array}$ \\
\hline Renewable energy sources & 17.71 \\
\hline Combustion technologies (CHP, CCPP) & 3.13 \\
\hline
\end{tabular}

\footnotetext{
${ }^{14}$ Specialisation is calculated considering the patents of the whole set of large firms as a reference. When firm $i$ is specialised in energy greentech, it means that its relative patenting activity in energy greentech (eg ) exceeds the average activity of the whole set of large firms.
} 


\begin{tabular}{|l|l|}
\hline Nuclear energy & 3.07 \\
\hline Efficient electrical power & 2.02 \\
\hline Biofuels & 2.86 \\
\hline Energy storage (batteries), hydrogen tech, fuel cells & 70.62 \\
\hline Total & 100.00 \\
Total number of patents & 72565 \\
\hline
\end{tabular}

Japanese firms representing about $23 \%$ of the firms in our dataset dominate the worldwide corporate greentech priority patenting by producing more than $55 \%$ of greentech patents applied for worldwide from 1994 to 2005 (Table 2). Europe and US, housing each about 1/3 of the firms, contribute each to $15 \%$ of worldwide corporate greentech patenting. This overwhelming contribution of Japan priority patents reflects a bias due to the heterogeneity in patent office rules that is particularly striking when considering patents at the Japan Patent Office ${ }^{15}$. Using transnational priority patents (patents applied for in at least two distinct patent offices) provides a less biased picture and alleviates the contribution of Japanese firms. However, Japanese firms still dominates to a large extend (45\%) the worldwide corporate energy greentech invention. Chinese and Korean firms are also large patentees with each $5 \%$ of the worldwide greentech patenting, a high share compared to their presence in the firm set. German firms contribute approximately to $2 / 3$ of European corporate greentech patents (around 10\%), French firms to $2.3 \%$ and the British firms to $0.8 \%$.

${ }^{15}$ Until recently, patents applied for at JPO had only one claim while in main western patent offices, each patent include several claims. Extending patents in other countries usually requires to group several patents applied for at JPO into a single patent applied for in another country. The ratio was estimated to be $3: 1$ or 5:1 (de Rassenfosse, 2013). 
Table 2: Contextual data on the contribution of firms to energy cleantech patenting across countries (1994-2005).

\begin{tabular}{|c|c|c|c|}
\hline Country of firms & $\begin{array}{l}\text { Distribution of } \\
\text { large firms }\end{array}$ & $\begin{array}{l}\text { Distribution of the } \\
\text { greentech patents of } \\
\text { large firms }\end{array}$ & $\begin{array}{l}\text { Share of greentech } \\
\text { patents from the large } \\
\text { firms }(\%)\end{array}$ \\
\hline United States & 34.00 & 15.24 & 28.80 \\
\hline Japan & 23.20 & 55.28 & 94.29 \\
\hline Germany & 9.20 & 9.73 & 25.95 \\
\hline United Kingdom & 6.20 & 0.78 & 22.11 \\
\hline France & 5.30 & 2.28 & 42.56 \\
\hline Switzerland & 2.90 & 0.44 & 90.78 \\
\hline Sweden & 2.90 & 0.44 & 26.85 \\
\hline Netherlands & 2.50 & 0.59 & 26.58 \\
\hline Finland & 1.90 & 0.19 & 32.13 \\
\hline Korea & 1.50 & 5.64 & 20.67 \\
\hline Belgium & 1.30 & 0.13 & 24.11 \\
\hline Canada & 1.20 & 1.44 & 26.17 \\
\hline Denmark & 1.20 & 0.27 & 7.56 \\
\hline Italy & 1.20 & 0.47 & 18.90 \\
\hline Taiwan & 1.20 & 0.99 & 7.33 \\
\hline Austria & 0.50 & 0.24 & 6.61 \\
\hline Norway & 0.50 & 0.20 & 18.54 \\
\hline Chına & 0.40 & 5.18 & 1.29 \\
\hline Brazil & 0.30 & 0.41 & 1.69 \\
\hline Total & 100.00 & 100.00 & 62.79 \\
\hline
\end{tabular}


The contribution of large firms to their home country total greentech patenting shows strong variations across countries (Table 2). Overall, large firms contribute to more than 6 over 10 patents in energy greentech. In Japan (or Switzerland), the greentech technological activity is performed almost exclusively by large firms while in the US and Europe, they are involved in $1 / 4$ to $1 / 3$ of the greentech patents of their home country. This share varies across EU countries: in France large firms contribute to approximately $50 \%$ of greentech but this share is below $10 \%$ in countries like Denmark or Austria.

In the pre-Kyoto period, the 946 firms filed 706524 priority patents; 11445 of them were energy greentech ones. In the post-Kyoto period, 882895 patents were applied for with 20273 energy greentech patents. In the decade, the number of energy greentech patents of firms has almost doubled and their distribution by greentech sectors has changed. The largest one "Energy storage, fuel cells and hydrogen technologies" received more and more attention from large firms: it concentrated $62 \%$ of the energy greentech patents in the pre- Kyoto period and $3 / 4$ of them ten years later. The second largest sector "Renewable energy" has declined from $20 \%$ to $16 \%$. To the exception of "Fuel of non-fossil origin", whose share remained stable to $2 \%$, the shares of other sectors have decreased. The drop was most marked in "Nuclear energy" (from $7.9 \%$ to less than $1 \%$ ) and "Technologies for efficient electrical power generation, transmission or distribution" (4\% to $1 \%)$.

\section{$4:$ Trends of the technological contribution of MNEs to energy greentech}

This section details the trends of the corporate greentech activity from the pre-Kyoto to postKyoto periods of time based on the 4 indicators previously defined.

\section{1 : Share of energy greentech firms across countries}


In the pre-Kyoto period, $36 \%$ of the large firms were green firms (i.e. they applied for greentech patents) (Table 3). This share has gained 10 points and reached $46 \%$ in the post- Kyoto period. The diffusion of energy greentech inventive activity among firms is more pronounced in European countries $(+50 \%)$ than in US $(+12 \%)$ or Asia $(10 \%)$. With $70 \%$ of its large firms already active in energy greentech in the 1990 s and $3 / 4$ of firms in the mid-2000s, Japan is a special case. This (large) share of Japanese green firms is about twice what is observed in western countries where approximately $1 / 3$ of large firms are green. In France and Italy the green activity of large firms is high. Conversely, Nordic countries and the UK show a low share of large green firms, like in the US. In Asia, it is worth noting that the share of green firms has sharply increased in the post-Kyoto period in Korea and Taiwan.

Table 3: Share of firms active in energy greentech across countries before and after the Kyoto Protocol $(\%)$

\begin{tabular}{|l|l|l|}
\hline \multirow{2}{*}{ Country* } & \multicolumn{2}{|l|}{ Share of large firms in greentech (\%) } \\
\cline { 2 - 3 } & $\mathbf{1 9 9 4 - 1 9 9 6}$ & $\mathbf{2 0 0 3 - 2 0 0 5}$ \\
\hline United States & 27 & 32 \\
\hline Japan & 70 & 77 \\
\hline Germany & 29 & 44 \\
\hline United Kingdom & 19 & 27 \\
\hline France & 36 & 46 \\
\hline Switzerland & 22 & 44 \\
\hline Sweden & 11 & 26 \\
\hline Netherlands & 25 & 33 \\
\hline Finland & 22 & 33 \\
\hline Korea & 57 & 86 \\
\hline
\end{tabular}




\begin{tabular}{|l|l|l|}
\hline Belgium & 8 & 17 \\
\hline Canada & 27 & 27 \\
\hline Denmark & 27 & 27 \\
\hline Italy & 45 & 55 \\
\hline Taiwan & 9 & 82 \\
\hline Total & 36 & 46 \\
\hline
\end{tabular}

*: only countries with more than 5 firms are shown

The new entry of large firms in energy greentech is thus a general trend among large firms in the post-Kyoto period.

4.2 Share of energy greentech in firms across countries before and after the Kyoto Protocol

Overall energy greentech technological activities were given more attention by firms over time: the share of greentech patents in firm portfolios has progressed from $1.62 \%$ to $2.30 \%$ within ten years (Table 4). This increasing commitment of firms to greentech is not homogenous across countries. Firms from Japan, France, Netherlands, Belgium and Denmark show the strongest growth. US and German firms hardly progressed at all and decreasing trends are even observed in Switzerland, Canada or Finland (the 2 first had already a high commitment in the pre-Kyoto period). In the mid-2000s, Japan, France, Belgium, Canada and Italy are the only countries for which large firms have more than $2 \%$ of energy greentech patents in their patent portfolios. Firms from Germany, the US, the UK or Korea lag behind.

Table 4: Share of greentech patents $\left(\mathrm{e}^{\mathrm{g}}\right)$ in firm patent portfolios across countries before and after the Kyoto Protocol 


\begin{tabular}{|l|l|l|}
\hline \multirow{2}{*}{ Country* } & \multicolumn{2}{|l|}{ Share of green patents (\%) } \\
\cline { 2 - 3 } & $\mathbf{1 9 9 4 - 1 9 9 6}$ & $\mathbf{2 0 0 3 - 2 0 0 5}$ \\
\hline United States & 1.01 & 1.14 \\
\hline Japan & 1.82 & 3.08 \\
\hline Germany & 1.48 & 1.51 \\
\hline United Kingdom & 0.64 & 0.87 \\
\hline France & 1.43 & 2.59 \\
\hline Switzerland & 2.88 & 1.08 \\
\hline Sweden & 0.71 & 0.56 \\
\hline Netherlands & 0.54 & 1.36 \\
\hline Finland & 0.70 & 0.36 \\
\hline Korea & 0.40 & 0.57 \\
\hline Belgium & 0.13 & 2.58 \\
\hline Canada & 5.09 & 2.19 \\
\hline Denmark & 0.82 & 1.40 \\
\hline Italy & 2.24 & 2.14 \\
\hline Taiwan & 0.29 & 0.48 \\
\hline Total & 1.62 & 2.30 \\
\hline
\end{tabular}

*: only countries with more than 5 firms are shown

4.3 Distribution of firm energy greentech specialisation across firm countries

In Asia, Japanese firms have a pronounced and durable specialization in greentech that has intensified over time: their specialisation index has grown from 1.13 to 1.34 (Table 5). Conversely, Korean or Taiwanese firms show an absence of greentech specialisation and have hardly progressed over the decade ( $\mathrm{G}$ has increased from 0.20 to 0.25 but remained far below 1). US firms that were not not specialized in greentech technologies in the pre-Kyoto period have not intensified but reduced their overall efforts later (their greentech specialisation index 
being respectively equal to 0.62 and 0.50 ). In Europe, diverse trends coexist. German firms that contribute approximately to more than half of European corporate greentech patents have a specialisation index reduced by $1 / 3$ in the post-Kyoto period (energy greentech was not among their main priorities). Such a drop in the greentech specialization index is also observed in Italy and in most of the small or Nordic European countries (except Belgium, Netherlands and Norway). Conversely, French firms have significantly reinforced their overall greentech specialisation and become specialised in energy greentech $(\mathrm{G}=1.13)$ in the post-Kyoto period.

Table 5: Firm greentech specialization index $(\mathrm{G})$ across countries before and after the Kyoto Protocol

\begin{tabular}{|l|l|l|}
\hline \multirow{2}{*}{ Country* } & $\begin{array}{l}\text { Greentech specialisation index of } \\
\text { large firms }\end{array}$ \\
\cline { 2 - 3 } & $\mathbf{1 9 9 4 - 1 9 9 6}$ & $\mathbf{2 0 0 3 - 2 0 0 5}$ \\
\hline United States & 0.62 & 0.50 \\
\hline Japan & $\mathbf{1 . 1 3}$ & $\mathbf{1 . 3 4}$ \\
\hline Germany & 0.91 & 0.66 \\
\hline United Kingdom & 0.40 & 0.38 \\
\hline France & 0.88 & $\mathbf{1 . 1 3}$ \\
\hline Switzerland & $\mathbf{1 . 7 8}$ & 0.47 \\
\hline Sweden & 0.44 & 0.24 \\
\hline Netherlands & 0.33 & 0.59 \\
\hline Finland & 0.43 & 0.16 \\
\hline Korea & 0.25 & 0.25 \\
\hline Belgium & 0.08 & $\mathbf{1 . 1 2}$ \\
\hline Canada & $\mathbf{3 . 1 4}$ & 0.95 \\
\hline
\end{tabular}




\begin{tabular}{|l|l|l|}
\hline Denmark & 0.51 & 0.61 \\
\hline Italy & $\mathbf{1 . 3 8}$ & 0.93 \\
\hline Taiwan & 0.18 & 0.21 \\
\hline
\end{tabular}

*: only countries with more than 5 firms are shown. Bold numbers indicate relative specialisation in greentech.

Our results show the leading position of Japanese firms in terms of their net contribution to greentech patents compared with their foreign competitors. They reveal as well that Japanese firms gave green technological activity a high and early priority as shown by their relatively high specialization already in the pre-Kyoto period. Being the greenest firms and still reinforcing their commitment to this field (the percentage of energy green patent in their patent portfolios has risen from $1.8 \%$ to $3.1 \%$ on average) Japanese firms are responsible for most of the progression of the worldwide corporate technological activity in energy greentech after the signing of the Kyoto Protocol. Large firms from a few other countries also performed well as they intensified their efforts in greentech. This is the case in France, Italy, Belgium and Canada.

\subsection{Firm specialisation in subsectors of energy greentech}

Firm greentech specialisation index across countries differ according to sectors of greentech (Table 6). In the pre-Kyoto period, US and EU firms were centred in Combustion and Nuclear energy (except Finland and the Netherlands for the latter), sectors where Japanese and Korean firms were not specialised. At that time Japanese firms were focused on new technologies in Transports (Batteries, fuel cells), Renewable energy and Non fossil fuel and their profile remains unchanged after the Kyoto protocol. In Korea, a high growth of specialisation in Combustion and Nuclear energy is visible. 
One striking feature of the post-Kyoto period is the pronounced decommitment to Nuclear Energy among US and EU firms (to the exception of France and the UK). Similarly, a despecialisation in Combustion emerges in most of the EU countries. The other significant feature emerging in the post-Kyoto protocol is the high growth of specialisation of US and EU firms in Renewable energy, in particular in small EU countries and in the UK. The specialisation index in renewable energy has also progressed in France and Germany but firms from these countries remain under-specialised $(\mathrm{SG}<1)$ compared to their competitors. Firms in most EU countries show also an increasing specialisation in Transport (batteries, fuel cell).

Table 6: Firm greentech specialisation index (SG) in main subsectors of energy greentech

\begin{tabular}{|c|c|c|c|c|c|c|c|c|c|c|}
\hline \multirow[t]{2}{*}{ Country } & \multicolumn{2}{|c|}{$\begin{array}{l}\text { Renewable } \\
\text { energy }\end{array}$} & \multicolumn{2}{|c|}{ Combustion } & \multicolumn{2}{|c|}{$\begin{array}{l}\text { Nuclear } \\
\text { energy }\end{array}$} & \multicolumn{2}{|l|}{$\begin{array}{l}\text { Non } \\
\text { fuel }\end{array}$} & \multicolumn{2}{|c|}{$\begin{array}{l}\text { Batteries, } \\
\text { fuel cell, } \\
\text { hydrogen }\end{array}$} \\
\hline & 94_96 & $03 \_05$ & 94_96 & 03_05 & 94_96 & $03 \_05$ & $94 \_96$ & 03_05 & $94 \_96$ & $03 \_05$ \\
\hline United States & 0.54 & 1.23 & 1.95 & 1.78 & 2.56 & 0.84 & 0.24 & 0.33 & 0.93 & 0.95 \\
\hline Japan & 1.09 & 1.03 & 0.61 & 0.73 & 0.64 & 0.75 & 1.12 & 1.10 & 1.04 & 1.01 \\
\hline Germany & 0.71 & 0.65 & 3.75 & 1.90 & 3.08 & 0.00 & 0.80 & 0.68 & 0.61 & 1.03 \\
\hline United Kingdom & 1.20 & 2.98 & 6.44 & 4.92 & 1.48 & 1.39 & 1.04 & 0.00 & 0.54 & 0.51 \\
\hline France & 0.42 & 0.70 & 4.57 & 4.03 & 4.50 & 9.58 & 0.31 & 0.23 & 0.51 & 0.85 \\
\hline Switzerland & 0.43 & 1.20 & 6.61 & 0.74 & 5.54 & 0.00 & 0.23 & 1.69 & 0.22 & 0.48 \\
\hline Sweden & 0.00 & 3.37 & 3.24 & 10.31 & 1.48 & 0.00 & 0.00 & 0.00 & 1.23 & 0.24 \\
\hline Netherlands & 2.07 & 1.09 & 2.10 & 1.05 & 0.00 & 0.00 & 0.00 & 0.60 & 0.75 & 1.01 \\
\hline Finland & 0.34 & 1.09 & 6.36 & 2.32 & 0.00 & 0.00 & 3.24 & 10.60 & 0.96 & 0.65 \\
\hline Korea & 0.80 & 0.45 & 0.00 & 2.04 & 0.51 & 3.90 & 0.00 & 0.00 & 1.24 & 1.06 \\
\hline
\end{tabular}


Bold numbers indicate relative specialisation in subsectors of energy greentech.

These data show that the post-Kyoto period is all over the world a period of rising commitment of firms to all sectors of energy greentech. However most European firms remained more active in traditional energy sector (except in a few small countries) and increased their activity in transport energy while US ones were more prone to develop technological skills in renewable energy.

\section{5 : Discussion of findings: role and strategy of major firms}

Based on the firm's home location, we follow the contribution of the firms to energy greentech in the pre-Kyoto and post-Kyoto periods and investigate if its intensity increased after the signing of the Kyoto Protocol. We aim at exploring if progress of large firms' commitment to energy greentech is linked to regional strategic policy regarding climate change issues or if, energy cleantech innovation being a global challenge, business competition for international market between large firms may be the major motivation for large firm involvement. In some sectors, the firm main responsibility could be linked to its capacity to propose technological solutions for the home country to respect its engagement towards greenhouse gas emission restriction (for example in the case of large public firms); in others, intensive competition for international market may be the dominant incentive (for example, the race for electric vehicles in the car industry).

5.1: The pre-Kyoto period highlights the leadership of Japanese firms in energy greentech 
In the pre-Kyoto period, Japanese large firms concentrated almost all the greentech inventive capacities of the country and all manufacturing industries were committed. Their early high greentech specialisation gave them an obvious advantage in the competition of large firms for cleantech innovation leadership over European and US corporations. Moreover Japanese MNEs were already specialized in new energy greentech technologies for energy production and energy storage (Renewable energies, Biofuel, Batteries, Fuel cell and Hydrogen technologies). This early and massive commitment of Japanese firms to greentech is at the origin of the leading role of the country in greentech as evidenced in the literature. It finds its roots in early strategic national $R \& D$ programmes ${ }^{16}$ set up to limit the country dependence on petroleum but also to maintain Japan as a high-tech superpower in the green 21 th century. In this perspective, firm technological greentech capacity fulfilled national strategic objective and built a dominating position in the new and promising international market of energy greentech. The commitment of firms from the US and most of the European countries differed strikingly from the Japanese firms. Overall, they were much less committed (lower share of greentech patents in patent portfolios, lower share of firms applying for greentech patents). Their contribution to the national greentech effort was much smaller and their greentech activities were centred on traditional energies such as nuclear energy and combustion. A large group of European countries including France, Germany, the UK, Switzerland and Sweden were strongly over-specialised in Nuclear Energy, Combustion and Electrical Efficiency but under-specialised in Renewable Energies (with the exception of the $\mathrm{UK}^{17}$ ). The

\footnotetext{
${ }^{16}$ For exemple, Sunshine or WE-NET programmes for photovoltaic or hydrogen technologies.

${ }^{17}$ The UK (like the Netherlands) hosts several international MNEs that locate their headquarter in the UK or in Caraïbian countries of in Commonwealth countries due to fiscal incentives (Shell, Tyco International ...) that may have strategies that differ from continental EU firms.
} 
Netherlands is the only western country among the main patentees where the firm specialisation in Renewable energy exceeded that of Japanese firms.

\section{2 : The early post-Kyoto period: a slightly modified landscape}

The leading position of Japanese firms in the mid-1990s has not been really challenged in the early post-Kyoto period. Neither European nor US firms have reinforced their contribution that still stagnated at $6 \%$ to $7 \%$ of the total large firms production in the post-Kyoto period; the US firm share has even declined. Japanese firms have confirmed and even intensified after Kyoto, the strategic orientations defined in the earlier period.

European and US firms did not follow a similar trend and the gap widened between Japanese and western firms. In 2003-2005, Japanese specialisation in energy greentech was twice that of European firms (only 1.5 time ten years before) and 2.7 that of US firms (twice ten years before). However, firms in western countries have started to move: the share of firms filing greentech patents and the share of greentech patents in firm portfolios have significantly increased in most countries (and industries). So firms from most western countries have diversified towards energy greentech and increased their inventive production in green technologies. However this process was slow and they still have stayed below the level reached in Japan ten years previous.

We find different strategies of greentech specialisation to comply with climate change mitigation set by the Kyoto protocol. The priorities of Japanese firms remained unchanged in the post-Kyoto period: they still focused on Renewable energies, Biofuel, Batteries and fuel cells. In US and Europe, different pictures emerged. Some countries remained highly 
engaged in traditional sources of energy (Nuclear energy, Combustion with SG far above 1) like France and the UK while most others have strongly decommitted from these sectors and focused on other sources of energy. This is the case in the US where large firms have massively decommitted from Nuclear Energy (and to a lower extent from Combustion) ${ }^{18}$ and significantly increased their involvement in Renewable Energy (SG has decreased by a factor 3 in Nuclear Energy and progressed by a factor 2.5 in Renewable Energy). Similar changes occur in small European countries (except in the Netherlands where firms were already highly involved in Renewable Energy in the 1990s). However the overall commitment of European firms to Renewable Energies is less marked than in US ones: while the specialisation index of the latter more than doubled, that of EU firms increased only by one- third on average at the continent level.

Firms from Germany, France and the UK did follow different trends. German firms have totally decommitted from Nuclear Energy but not from Combustion. In the UK, firms still focused on traditional energy. French firms show a weak investment in new energy greentech for energy production and remain under specialised $(\mathrm{SG}<1)$, a trait which reflects the strong reliance of that country on nuclear resources (Cosatea, 2014). Besides this trend of sustained reliance on traditional energies, all EU countries have increased their specialisation index in new sources of energy or energy storage. The investments of firms in Germany, France and

\footnotetext{
${ }^{18}$ The disengagement of US large firms from Nuclear Energy in the mid-2000s was also observed by Albino (2014) on a smaller set of patents. He explains how opposite trends coexisted: one the one hand, nuclear accidents (Three Miles Islands (1979) and Tchernobyl (1986)) had conducted countries like Italy, UK or Germany to reconsider their programme in Nuclear energy but, on the other hand, oil prices, interest of developing countries and environmental concerns lead to a nuclear renaissance in the late 1990s. Our results indicate that in 2003-2005, US large firms followed the first trend.
} 
Italy are balanced between wind energy, PV and solar energy ${ }^{19}$. In smaller countries, they are more specialized: wind energy in Sweden; solar energy in the Netherlands. The post-Kyoto evolution also concerns the sector of transport energy (batteries, hydrogen technology and fuel cell) where large firms from most EU countries have reinforced their contributions. German firms took the lead and the new specialisation in batteries, fuel cells and hydrogen technologies emerged from the car industries, a sector of growing importance in patenting in the 2000 s (Laurens \& al., 2015).

\section{3 : Regional responses of firms to the Kyoto Protocol}

In the early post-Kyoto period, the issue of the impact of energy on climate change has been addressed differently by firms according to their geographic locations. Coming back to our four initial questions, the evolutions in the decade from the pre- to the post Kyoto period shown in Table 6 can be summarized as follow:

- Diversification of corporate patent portfolios in favour of green technologies is a global trend shared worldwide. On average, European firms were more prone to diversification than US ones but they still lag far behind Japanese firms that strongly diversified much earlier.

- $\quad$ The patent portfolios of firms became greener in the post-Kyoto period. However its trend remained "light green" in western countries as it turned comparatively to “intense green" in Japan.

${ }^{19}$ The firms' commitment in the subsector Renewables was investigated more in details. Data are not shown here. 
- $\quad$ Compared to Japan, highly specialized in energy greentech and still reinforcing it in the post Kyoto period, EU firms and even more US firms are losing ground in the battle for green from the pre- to the post- Kyoto period. As noted by Acemoglu et al. (2012) delay in intervention in favor of green technologies is costly. A soon and strong policy response is far better.

- This apparent relative decreasing specialization of US and EU firms has to be considered with care. It results mainly from the decommitment from Nuclear energy and Combustion in many (but not all) countries. Signals of an early commitment to Renewable energy and Energy storage is evident in most western countries in the post Kyoto period. Its intensity is more pronounced in the US compared to EU. However EU mixes diverging trends and small EU countries adapt faster ${ }^{20}$.

Table 6: Changes from the pre- to the post Kyoto period according to four indicators

\begin{tabular}{|l|l|l|l|l|}
\hline Indicator & $\begin{array}{l}\text { Number of firms } \\
\text { in energy green }\end{array}$ & Share of greentech & Greentech & Specialisation in \\
& in patent portfolio & specialisation & greentech sub- \\
technology & $\left(\mathrm{e}^{\mathrm{g}}\right)$ & index (G) & sector (SG)
\end{tabular}

${ }^{20}$ The size of the market that plays an important role favoring abundant inputs (according to Acemoglu, 2002) should have a positive effect on fossile energy research in large countries as the USA. Surprisingly it appears not in our findings. 


\begin{tabular}{|c|c|c|c|c|}
\hline Japan & $\begin{array}{l}+10 \% \\
\text { Already high in } \\
\text { the first period } \\
\text { incremental } \\
\text { growth between } \\
\text { the two periods }\end{array}$ & $\begin{array}{l}+66 \% \\
\text { Starting from a } \\
\text { high share in the } \\
\text { first period }\end{array}$ & $\begin{array}{l}+20 \% \\
\text { Already } \\
\text { specialised in the } \\
\text { first period }\end{array}$ & $\begin{array}{l}\text { Unmodified } \\
\text { Specialisation in } \\
\text { renewables, and } \\
\text { new energy storage }\end{array}$ \\
\hline US & $\begin{array}{l}+20 \% \\
\text { Moderate in the } \\
\text { first period } \\
\text { Slight increase } \\
\text { the second period }\end{array}$ & $\begin{array}{l}+10 \% \\
\text { Moderate in the } \\
\text { first period }\end{array}$ & $\begin{array}{l}-20 \% \\
\text { Reinforcing its } \\
\text { under- } \\
\text { specialisation in } \\
\text { the first period }\end{array}$ & $\begin{array}{l}\text { Changed } \\
\text { Strong } \\
\text { decommitment } \\
\text { from Nuclear } \\
\text { Strong } \\
\text { involvement in } \\
\text { Renewable }\end{array}$ \\
\hline Europe & $\begin{array}{l}+30 \% \\
\text { High or weak } \\
\text { growth according } \\
\text { to the countries }\end{array}$ & $\begin{array}{l}+10 \% \\
\text { Diverse evolutions: } \\
\text { large increase } \\
\text { (Germany, France, }\end{array}$ & $\begin{array}{l}\text { Global stability } \\
\text { but variation } \\
\text { across countries } \\
\text { Reinforced }\end{array}$ & $\begin{array}{l}\text { Situation varies } \\
\text { across countries } \\
\text { Decommitment } \\
\text { from Nuclear }\end{array}$ \\
\hline
\end{tabular}




\begin{tabular}{|l|l|l|l|}
\hline & Netherlands, & specialisation & (except in France) \\
& $\begin{array}{l}\text { Denmark), } \\
\text { stagnation (Italy) }\end{array}$ & (France, & Netherlands, \\
or severe decrease & Denmark) & Involvement in \\
(Switzerland, & Renewable or \\
& Sweden, Finland) & (Germany, UK, & \\
& & Sweden, Italy) & \\
\hline
\end{tabular}

Our findings, showing that US firms have taken on the issues of renewable energy before most of those from EU countries, contradict Cogan (2006) who states that in the mid-2000s American firms addressing climate change at the governance level were catching up with their international competitors. They are, however, in accordance with the situation depicted by Falkner (2010) where many large US companies (Ford, Chryler, General Motors, Texaco) started to align their strategies at the end of the 1990 s by taking into consideration the signature of the Kyoto protocol despite the official opposition of the US government. This overall evolution of US large firms could suggest that large firms are less sensitive to the fluctuating regional political signals in terms of engagement of the government fostering local technological choice and more prone to investigate new technological sectors as soon as they detect international market opportunities. This relates to the competitive risk linked to the regulatory risk in the global and domestic marketplaces described by Cogan (2006).

US industry needs to close the spending gap with counterparts in Japan to remain competitive at the cutting edge of technology and innovation in energy greentech, a gap that not all EU firms were aware of. Our results on EU firms fit well the statements of Aghion \& Veugelers (2009) according to which the "private innovation machine" has not taken off in the case of EU MNEs due to the design of political instruments that do not provide enough incentives to 
invest in clean innovation and due to the lack of coordination among EU countries ${ }^{21}$. Additionally, a lack of coordination at the EU level in the sector of energy that contrasts with the focused energy technology policy in the US and Japan (Wiesenthal, 2011) could have delayed the EU large firm commitment to new energy cleantech.

Firms answer to the climate change challenge is also dependent on the industrial sectors themselves $^{22}$. We have yet to consider this dimension in our geographical analysis at the country level. Different national industry profiles could explain the different observed behaviours concerning the greentech commitment of large firms. The commitment of industrial sectors among countries was already the subject of an extensive study carried out by Frankhauser (2013) analysing all greentechs (and not only in the energy sector) between 2005 and 2007. Our study while restricted to the energy greentech sector and covering a previous period of time evidences rather similar results ${ }^{23}$.

\footnotetext{
${ }^{21}$ Using data from CIS 2006 survey they have found that among possible motives for innovation, those related to improving energy effiency and reducing the enrironmental impact were the less often cited motives for explaining innovation.

${ }^{22}$ It is for example well documented that Utility industries or other industries extensively relying on energy are more prone to be committed to greentech. We have observed similar trends in our data and the sectoral profile of countries matters and more strikingly in small countries with a small number of large firms (for example the dominating Industrial Machinery sector in Austria, Norway or Sweden explains the green affinity of these countries). This is also the case of the energy supplying industry, for large public firms like Electricité de France, Areva (France), Vatterfall (Sweden) or Hydro- Quebec (Canada).

${ }^{23}$ However one main difference relates to the predominent role of Utilities in our study that did not emerge in their multisector greentech work.
} 


\section{Conclusion: the role of policies and firm strategies}

In this study, we contribute to the literature on greentech inventions across countries and in different technologies ${ }^{24}$ by focusing attention on the role played by large multinational firms. The leading role of multinational companies in the growth of the green sector was assessed by OECD (Kalamova, 2011; Corsatea, 2014) as well as the importance of clear and continuous national public policies to promote both greentech technology development and market demands. However to our knowledge no research has ever studied to which extend such large contributors to the technological progress have participated in the take off of the "green innovation machine" (Aghion and Veugelers, 2009) ${ }^{25}$.

We use a unique set of corporate patent data applied for by the firms with the largest $R \& D$ investments among the world and restrict the study to those that have a sustained patenting activity. Conversely to most studies that used restricted sets of patents meeting a certain quality threshold when selecting triadic patents, PCT patents, patents applied at USPTO or EPO for monitoring technological developments, we analyse a broader set of patents by including all priority patents applied for, without any restriction. In order to deal with institutional bias associated to priority patent, we most often use relative specialization index and compare corporate activities in greentech and non greentech to assess the distribution of greentech invention among large firms depending on the firm country and on the contribution

\footnotetext{
${ }^{24}$ See among others: Johnstone $(2010,2011)$ and Dechezleprêtre (2009)

${ }^{25}$ Our study targeting large firms does not give information on country's overall activity in energy greentech nor allow any comparison between countries.
} 
of large firms innovation to the global greentech innovation in the firm's country. Our main findings are the following ${ }^{26}$ :

1. The contribution of large firms to greentech patenting varies according to countries and greentech sectors. In Japan all the greentech technological activity originates from large firms. In US and Europe, large firms are involved in $1 / 4$ to $1 / 3$ of the greentech patents ${ }^{27}$.

2. The sector of the transport energy (battery, fuel cell) is the sector where the firm commitment is the strongest.

3. Japanese and US firms are highly committed to renewable energies.

4. The post-Kyoto period is a period of growing commitment of firms to all sectors of energy greentech. European firms tend to remain more active in traditional energy sector and transport energy while US ones develop skills in renewable energy.

5. There is a large heterogeneity across European countries in terms of shares of greentech, index and profile of greentech specialisation

Coming back to the diffusion perspective presented in the introduction, our more important finding is that the Kyoto Protocol has deeply transformed the game. Our sample of large multinational firms makes appear a massive trend in favour of the diffusion of energy greentech. A growing number of firms produce energy greentech inventions and the overall

\footnotetext{
${ }^{26}$ We do not provide any assessment of the enviromental benefits of the MNEs technological activity in clean energy sector (as realized by Gilli et al., 2013; Ghisetti and Quatraro, 2014; Mazzanti and Zoboli, 2009).

${ }^{27}$ More than $83 \%$ of corporate greentech patents produced worldwide originate from Japanese firms while US and European firms contribute to $6 \%-7 \%$ of corporate greentech. But this counting is clearly due to the bias provided by the use of priority patenting.
} 
share of greentech has increased significantly - a tendency that has already been identified by Veugelers $(2014)^{28}$ for the total population of patentees. Kyoto protocol may be interpreted as a signal opening a new area of a stronger environmental regulation. As such it has triggered a wave of environmental inventions (Borghesi et al., 2015). This result has an important meaning: overall, the firms have started a virtuous development of their knowledge capacity in the field of energy greentech, entering a learning process in energy green technology. Our work confirms the study by Nicolli et Vona (2014) stating that the ratification of the Kyoto protocol - determining a more stable and less uncertain policy framework - has amplified the green innovation inducement effect of both energy policy and market liberalization.

In the technological competition between green and "dirty" technologies all factors providing additional benefits to the green energy technologies are worthy. We can thus expect the firms to switch to effective green energy technologies in a near future. Our index of specialisation (that is less an indicator of diffusion than a marker of internal specialisation) provides a less clear picture. That is in line with what Popp et al. (2011) report on the diffusion of renewable energy that reveals leaders and laggards. Maybe the most important sources of differences across countries will stem from national differences in environmental policy (what report Popp et al. (2011) as well). Our work confirms the private green energy machine cannot be effective without any public support (Veugelers, 2011).

\section{References:}

Acemoglu, D. (2002) Directed Technical Change. Review of Economic Studies 69(4): 781810

\footnotetext{
${ }^{28}$ The upward trend is particularly strong for solar PV, wind and carbon capture.
} 
Acemoglu, Daron, Philippe Aghion, Leonardo Bursztyn, and David Hemous. (2012) The Environment and Directed Technical Change. American Economic Review 102(1): 13166

Aghion P., Harris C., Howitt P., Vickers J. (2001) Competition, imitation and growth with step- by-step innovation. The review of Economic Studies 68: 467-492

Aghion P., Veugelers R., Serre C. (2009) Cold start for the green innovation machine. Bruegel Policy contribution $N^{\circ} 2009 / 12$

Albino V., Ardito L., Dangelico R.M., Petruzzelli A.M. (2014) Understanding the development trends of low-carbon energy technologies: A patent analysis. Appl Energy. doi.org/10.1016/j.apenergy.2014.08.012

Antonelli C., (ed.) (2011) Handbook on the economic complexity of technological change. Edward Elgar, Cheltenham

Begg K., van der Woerd F., Levy D.L. (2005) The business of climate change: Corporate responses to Kyoto. Greenleaf Publishing, Sheffield (UK)

Borghesi, S., Cainelli, G., Mazzanti, M (2012) Brown Sunsets and Green Dawns in the Industrial Sector: Eco Innovations, Firm Behavior and the European Emission Trading. Working Paper 3. Fondazione Eni Enrico Mattei

Borghesi S., Cainelli G., Mazzanti, M., (2015) Linking emission trading to environmental innovation: Evidence from the Italian manufacturing industry. Research Policy 44(3): 669683

Breschi, S., Lissoni, F., Malerba, F. (2003) Knowledge relatedness in firm technological diversification. Research Policy 32(1): 69-87

Christmann P. (2004) Multinational companies and the natural environment: Determinants of global environmental policy. Academy of Management Journal 47: 747-760

Christmann P., Taylor G. (2001) Globalization and the environment: Determinants of firm self-regulation in China. Journal of International Business Studies 37: 439-458

Cogan, D.G. (2006) Corporate Governance and Climate Change: Making the Connection. Published by CERES 2006, Boston, MA

Cohen W.M., Levinthal D.A. (1990) Absorptive capacity: A new perspective on learning and innovation. Administrative Science Quaterly 35: 128-152

Corsatea T.D. (2014) Technological capabilities for innovation activities across Europe: Evidence from wind, solar and bioenergy technologies. Renewable and Sustainable Energy Reviews 37: 469-479 
de Rassenfosse G., Dernis H., Guellec D., Picci L., van Pottelsberghe de la Potterie B., (2013) The worldwide count of priority patents: A new indicator of inventive activity. Research Policy 42: 720-737

Dechezlepretre A., Glachant M. Meniere Y. (2009) What drives the international transfer of climate change mitigation technologies?: empirical evidence from patent data. Centre for Climate Change Economics and Policy and Grantham Research Institute on Climate Change and the Environment, London, UK.

Dechezleprêtre A., Glachant M., Hascic I., Johnstone N., Ménière Y. (2011) Invention and transfer of climate change-mitigation technologies: a global analysis. Review of Environmental Economics and Policy 5 (1): 109-130

Deegan C., Gordon B. (1996) A study of the environmental disclosure policies of Australian corporations, Accounting and Business Research 26, 187-199

Falkner R. (2010) Business and Global Climate Governance: A Neo-Pluralist Perspective in Business and global governance, Chapter 5, published by Routledge, Taylor \& Francis Group

Fankhauser S. (2013) Who will win the green race? In search of environmental competitiveness and innovation. Global Environmental Change 23: 902-913

Foster R., Ghassemi M., Alma C.S (2010) Solar Energy: Renewable energy and the environment. Energy and the Environment Series, CRC Press, Taylor and Francis group.

Ghisetti C., Quatraro F., (2014) Is green knowledge improving environmental productivity? Sectoral evidence from Italian regions. Workings Papers series 11/14. Department of Economics and Statistics "Cognetti de Martiis"

Gilli M., Mancelli S., Mazzanti M., (2013) Innovation Complementarity and Environmental Productivity Effects: Reality or Delusion? Evidence from the EU. FEEM Working Paper No. 88.2013

Grant R.M. (1996) Prospering in Dynamically-Competitive Environments: Organizational Capability as Knowledge Integration. Organization Science 4: 375-387

Griliches Z. (1990). Patent Statistics as Economic Indicators: A Survey. Journal of Economic Literature 28(4): 1661-1707

Horbach J., Rammer C., Rennings K. (2011) Determinants of Eco-innovations by Type of Environmental Impact: The Role of Regulatory Push/Pull, Technology Push and Market Pull, ZEW Discussion Paper N¹1-027

Industrial R\&D Investment Scoreboard Report (2008) from the Institute for Prospective Technological Studies of the European Commission IPTS. (downloaded on 12 November 2013 from http://iri.jrc.ec.europa.eu/scoreboard12.html) 
Jaffe A., Newell R., Stavins R. (2003) Technological change and the environment, in: Mäler, K., Vincent, J., (Eds.), Handbook of Environmental Economics, chapter 11. Elsevier, pp. 461516

Johnstone N., Hascic I., Popp D. (2010) Renewable energy policies and technological innovation: evidence based on patent counts. Environmental and Resource Economics 45: $133-155$

Kalamova M, Kaminker C, Johnstone N (2011) Sources of Finance, Investment Policies and Plant Entry in the Renewable Energy Sector, OECD Working Papers 37 doi.org/10.1787/5kg7068011hb-en

Kaya O. (2008) Companies Responses to Climate Change: The Case of Turkey. European Journal of Social Sciences 7(2): 53-62

Kemp R. and Foxon T. (2007) 'Typology of eco-innovation', European Project 'Measuring eco-innovation' (Call FP6-2005-SSP-5A, Area B, 1.6, Task 1)

Lang M., Lundholm R. (1993) Cross sectional determinants of analyst rating corporate disclosures. Journal of Accounting Research 31: 246-271

Lanjouw J., Mody A. (1996) Innovation and the international diffusion of environmentally responsive technology. Research Policy 25: 49-571

Laurens P., Le Bas C., Schoen A., Villard L., Laredo P. (2015) The rate and motives of the internationalisation of large firm R\&D (1994-2005): Toward a turning point? Research Policy 44: $765-776$

Levy D.L., Kaplan R. (2007) CSR and Theories of Global Governance: Strategic Contestation in Global Issue Arenas. The Oxford Handbook of CSR. Edited by Andrew Crane, Abagail McWilliams, Dirk Matten, Jeremy Moon and Donald Siegel. Oxford University Press

McWilliams A. and Siegel D. (2000) Corporate Social Responsibility and Financial Performance: Correlation or Misspecification? Strategic Management Journal, 21(5): 603-609

Margolick M. Russell D. (2001) Corporate Greenhouse Gas Reduction Targets. Washington DC: Pew Center on Global Climate Change

Mark A.D., Siddharth S. (2012) Green Growth, Technology and Innovation. World Bank Policy Research Working Paper No. 5932 World Bank, Washington DC, USA

Mazzanti M., Zoboli R. (2009) Environmental efficiency and labour productivity: Trade-off or joint dynamics? A theoretical investigation and empirical evidence from Italy using NAMEA, Ecological Economics, 68(4): 1182-1194

Mowery D.C., Nelson R.R., Martin B.R. (2010) Technology policy and global warming: Why new policy models are needed (or why putting new wine in old bottles won't work). Research Policy 39: 1011-1023 
Nicolli F. and Vona F. (2014) Heterogeneous policies, heterogenous technologies : the case of renewable energy. Sciences Po publications 2014-15, Sciences Po

Nidumolu R., Prahalad C.K., Rangaswami M.R. (2009) Why Sustainability Is Now the Key Driver of Innovation. Harvard Business Review, September, 56-64

Oltra V. and Saint Jean M., (2009) Sectoral system of environmental innovation: An application to the French automotive industry. Technological Forecasting and Social Change 76: $567-583$

Parnick R., Wilder C. (2007) The Clean Tech Revolution: The next big growth and investment opportunity published by Harper Collins

Popp D. (2005) Lesson from patents: Using patents to measure technological change in environmental models. Ecological Economics 54: 209-226

Popp D., Hascic I., Medhi N. (2011) Technology and the diffusion of renewable energy. Energy Economics 33: 648-662

Reinhardt, F.L. (2000) Global Climate Change and BP Amoco.Harvard Business School Case Study 9: 700-106

Rennings K. (2000). Redefining innovation -- eco-innovation research and the contribution from ecological economics. Ecological Economics 32(2): 319-332

Sterlacchini A. (2012) Energy R\&D in private and state-owned utilities: An analysis of the major world electric companies, Energy Policy 41: 494-506

Strike V., Gao J. Bansal P. (2006) The (IR) Responsibility of multinational enterprises. Academy of management Proceedings - meeting Abstract Supplement A1-A6. Swann G. M. P. (2009) The Economics of Innovation. An introduction. Edward Elgar.

Veefkind V. Hurtado-Albir J., Angelucci S., Karachalios K., Thumm N. (2012) A new EPO classification scheme for climate change mitigation technologies. World Patent Information 34: 106-111

Verdolini, D., Galeotti, M. (2011) At home and abroad: an empirical analysis of innovation and diffusion in energy technologies, Journal of Environmental Economics and Management, 61(2): 119-134

Veugelers R. (2011) Which intruments to induce clean innovating. Research Policy 41: 17701778

Veugelers R. (2014) What Innovation policies for ecological transition? Powering the green innovation machine. Working Paper $n^{\circ} 73$. Dec. WWWFOREUROPE

Wiesenthal T., Leduc G., Haegeman K., Schwarz (2012) H.G. Bottom-up estimation of industrial and public R\&D investment by technology in support of policy-making: The case of selected low-carbon energy technologies. Research Policy 41: 116-131 